\title{
LEGAL AND TECHNICAL ASPECTS OF MODERNIZATION OF LAND AND BUILDINGS CADASTRE IN SELECTED AREA
}

\author{
Monika Siejka, Marek Ślusarski, Monika Mika \\ Department of Land Surveying \\ University of Agriculture in Krakow, Poland
}

\begin{abstract}
Modernization of the land and buildings cadastre is a set of actions aimed at improving the quality of data collected there. Application in the process of modernization of the sources of information from the land surveying, gives fully satisfactory results. On the other hand the use of photogrammetric measurements is the solution more economical in terms of financial and time. However, there is a danger of obtaining the results which do not meet the standards of accuracy of the border points position. The paper presents an example of the results of the influence of the process of modernizing the land and buildings cadastre for the areas where the source material are cadastral maps in the scale 1: 2000, created on the basis of photomaps or cadastral maps in the scale 1: 2880. An assessment of the suitability of these materials in the process of modernization and their impact on the current form of the land and building cadastre as a public register was made.
\end{abstract}

Keywords: cadastre, cadastral map, geoinformation database

\section{Introduction}

According to the Law of Geodesy and Cartography, land and buildings cadastre $(E G i B)$ is understood as an information system that ensures the collection, updating and sharing, in a uniform manner for the whole country, information on land, buildings and premises, their owners and any other entities administering or managing the land, buildings or premises.

The current state of the real estate cadastre in Poland comes from the thirteenthcentury tradition of land management and is the result of changes due to historical events in Central Europe. An important appears to be that, despite many historical obstacles, such as wars, conquests and the communist regime, the efforts to create an efficiently functioning cadastral system were not stopped (Mika and Siejka, 2012). Subsequent changes of the legislation are moving towards the creation of fully 
valuable system recording descriptive data relating to real estate and all rights assigned to it (especially the right of property ownership).

In the ongoing surveying works the source documents are often cadastral maps dating back to the time when our country land belonged to individual partitions (Prussian, Austrian). In the case study analyzed later in the publication, observed are the traces of the transformation of cadastral data due to the following regulations:

- Regulation of the Minister of Building dated December 6, 1950 on the procedures for the organization, establishing and running land and building cadastre,

- Decree of 2 February 1955 on land and buildings cadastre,

- Regulation of the Ministers of Agriculture and Municipal Economy of June 28, 1955 on the procedures for the reporting and making changes in the data included in the land and buildings cadastre,

- Regulation of the Ministers of Agriculture and Municipal Economy of February 20, 1969 on the land cadastre,

- Regulation of the Ministers of Land Management and Building and Agriculture and Food Economy of December 17, 1996 on the the land and building cadastre,

- Regulation of the Minister of Regional Development and Building of March 29, 2001 on the the land and building cadastre,

- Regulation of the Minister of Administration and Digitization of November 29, 2013 changing the regulation on the the land and building cadastre.

The observed changes in the above-mentioned legal provisions result in each case in a significant reorganization of the way of obtaining, recording, maintaining, updating, processing and sharing of data. This fact implies a diversity of data quality concerning the cadastral entities (owners and administers) and objects.

In the professional literature often conflicting opinions can be found on the possibility of using cadastral maps to build full value cadastral system. According to (Przewięźlikowska and Skotnicki, 2001; Hanus et al, 2013) these data may serve as the basis for the establishment of the future real estate cadastre. If, however, their use for the above mentioned purpose in the former Prussian partition seems to be indisputable, because of their high accuracy and reliability, on the other hand, their use for purposes of selected objectives of the real estate cadastre in areas of the former Austrian partition may be associated with specific problems. The scale these problems is clearly visible on the research area presented in this work.

The paper presents an example of the results of the influence of the process of modernizing the land and buildings cadastre $(\mathrm{EGiB})$ for the areas where the source material are cadastral maps in the scale 1: 2000 (created on the basis of photomaps) or cadastral maps in the scale 1: 2880. The aim of this paper is to analyze the usefulness of these materials and to present their influence on the present graphic data form of the land and building cadastre as a public register.

\section{The genesis of the problem}

Modernization of the land and buildings cadastre (EGiB) register is a set of technical, organizational and administrative actions aimed at improving the quality of data collected there. The modernization works are carried out in a continuous and comprehensive way. Continuous modernization takes place in the context of the current updating the cadastre records, by introducing documented changes to the cadastre database. The complex modernization is performed throughout the whole 
precinct, its purpose is to modify the cadastre database in accordance with the requirements laid down by law.

Adopted in 1989 Law of Geodesy and Cartography, imposed a duty to determine by regulation principles of establishing and managing $E G i B$ and the detailed scope of information covered by the records. Until announced in 1996 first regulation on EGiB, descriptive part of the cadastre records was computerized for the whole country. Work has started on changing the form of the cadastral map from the analog to digital. Regulation of 1996 says, that land and building cadastre is one coherent information collecting cadastre data in the form of computer descriptive data files and in the form of digital map. The goals and steps of EGiB modernization were defined. The main objectives are: change of its operating techniques, unification of the scope of the information, documenting of the course of borders and co-operation with the mortgage registers system. Modernization of $\mathrm{EGiB}$ in this period consisted in the introduction of information systems integrating computer descriptive data sets with the cadastral maps. Work was also carried on developing digital cadastral map based on geodetic documentation (technical reports) and analog map.

The Regulation of 2001 defined the modernization of EGiB as a set of activities undertaken, among others to modify the cadastral database in accordance with the requirements of this Regulation. Cadastral data set for a parcel includes, among others, a numeric description of its boundaries (coordinates of the points defining the course of the border). Therefore, the coordinates of the boundary points of the cadastral parcels should be determined with the accuracy required for the first group of land details. It should be noted that the only way to obtain the required accuracy are land surveying. However, §82.1 allows to use for the numerical description of the parcels boundaries, materials and data of the National Geodetic and Cartographic Resource even if they do not meet the requirements of the applicable technical standards. Condition for using these materials to determine and measure the boundary points of cadastral parcels is the possibility of obtaining the accuracy of not less than: 3,0 m - in rural precincts and 0,60 $\mathrm{m}$ - in urban precincts (with the respect to detailed geodetic network). Area of the cadastral parcels shall be adopted on the basis of existing records, if the position of the boundary points was determined on the basis of data not satisfying the requirements of the applicable technical standards. Therefore, in accordance with the provisions of this Regulation, the work was carried out, where the principal purpose was the establishment of the cadastre of buildings. Regulation on EGiB in force since 2014 has introduced significant changes to rules governing the carrying out of cadastre modernization. The distinction between continuous and comprehensive modernization was abandoned. Digital description of the cadastral parcels boundaries is realized by means of border points, position of which relative to the geodetic network of the 1st grade has been determined on the basis of geodetic surveys with the mean square error not exceeding $0,30 \mathrm{~m}(\$ 61.1)$. This provision precludes the possibility of the use of other than surveying techniques, to create a numerical description of the boundaries of cadastral parcels. However, in the performance of the modernization, one of the objectives of which is to convert the cadastral map from analogue to electronic form, the materials of the National Geodetic and Cartographic Resource can be used, but to a limited extent. Position error of border points (in relation to the 1 class geodetic network) must not exceed $3.0 \mathrm{~m}$ - for rural areas beyond the densely built areas and 0,60 $\mathrm{m}$ - for urban areas and rural densely built areas. In addition, the provision that allowed to keep in the registry the area of the parcels from the records of the previous cadastre has been 
removed, even if the position of the boundary points was determined on the basis of data that did not meet the requirements of the applicable technical standards.

According to the provisions of the amended Regulation, since 2014 use of cadastral maps at scales 1:2000, 1:2880 i 1:5000, during the modernization, is only possible for cadastral parcels located in rural areas outside the densely built areas. In urban areas and rural densely built areas, only materials that meet the requirements of the applicable technical standards can be used. In the absence of such documentation data concerning the course of borders of cadastral parcels must be obtained by land and photogrammetric measurements preceded by determining the course of borders.

\section{Research and analysis of results}

Work carried out in this study was performed on 40 cadastral precincts located in rural areas. In the area covered by the scope of the current research a comprehensive modernization of land cadastre is carried out. According to the regulation in force on $E G i B$, vertices of borders must originate from one of the nine data sources. For the analyzed objects information was collected on the number of parcels in a given precinct meeting the particular data source criteria. On the basis of the analyzed material the following data sources were selected (named as ZRD):

1. existing in National Geodetic and Cartographic Resource data meet the precision criteria set out in the $\S 61.1$ of the regulation on EGiB (named as ZRD1),

2. land surveying preceded by determining the course of borders (named as ZRD2),

3. photogrammetric measurements preceded by determining the course of borders (named as ZRD3),

4. photogrammetric measurements not preceded by determining the course of borders (named as ZRD4),

5. screen vectorization of cadastral raster map without the use of linear measurement (named as ZRD5).

For the 20 examined cadastral precincts in geodetic resource a cadastral map is kept in scale 1: 2000. This map was created in the 70's and 80's of the twentieth century, based on photogrammetric description in the form of a photomap (Cymerman et al, 1982; Fedorowski, 1974; Hycner, 2004). This method of determination of the borders was used for approximately $25 \%$ of the cadastre precincts in the country (Wilkowski 2005; Wilkowski et al, 2006). In accordance with the applicable technical instruction K-1, the accuracy of the details of such a study for the first group of precision (borders of parcels), could not be less than $\pm 0.4 \mathrm{~mm}$ in the map scale. Therefore, for the cadastral maps in the scale 1:2000, created from photogrammetric materials, position error of border point should not be less than 0.8 $\mathrm{m}$. However, in practice, the accuracy of such map is lower. In Polish southern areas, especially in the mountain and foothill areas, it does not exceed the range from $1.5 \mathrm{~m}$ to $2.0 \mathrm{~m}$ (for details of first precision group). In this situation, in accordance with provisions currently in force, cadastral maps created on the basis of photomaps can be the basis for the determination of cadastral parcels border points, located only in rural areas outside the densely built areas.

Figures 1 and 2 show parts of cadastral maps before and after the modernization. Figure 1 shows borders of parcels identified on the basis of the cadastral maps in the scale 1: 2880 . It shows clearly, that the boundaries of the parcels were determined according to the actual state of the usage omitting the original borders of the 
cadastral parcels. At example of the parcel No. 2211/7 it can be seen, that the border of usage determined by the fence clearly stands out from the course of cadastral parcel borders. When they are displaced parallelly one to another, right is the conclusion, that this situation is the result of inaccurate local fitting of the cadastral maps into the existing land situation. In this situation, the legitimacy of the state of use is correct. However, this does not solve the problem of identifying the borders of land in whole or in part undeveloped. An additional problem is to determine the course of borders of the parcels used as communication areas. In the vast majority of cases, areas used as roads do not coincide with the cadastral borders (parcel number 2137/1).

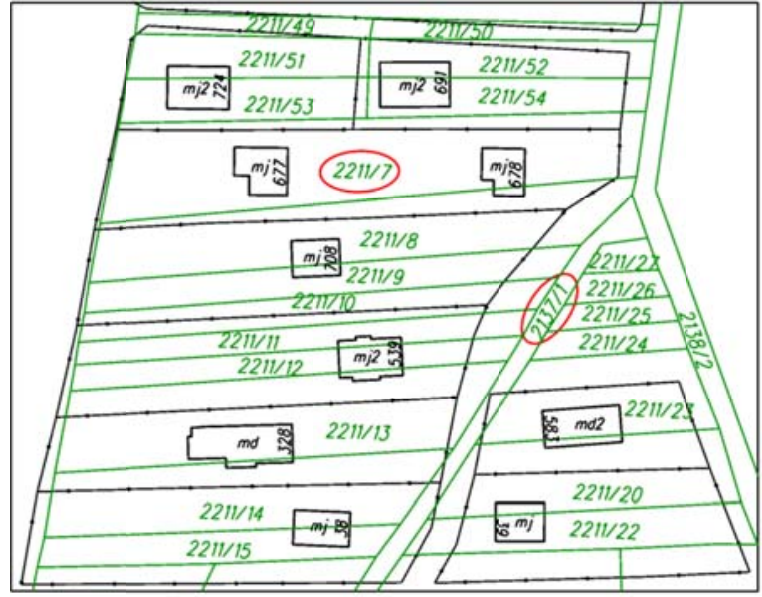

a)

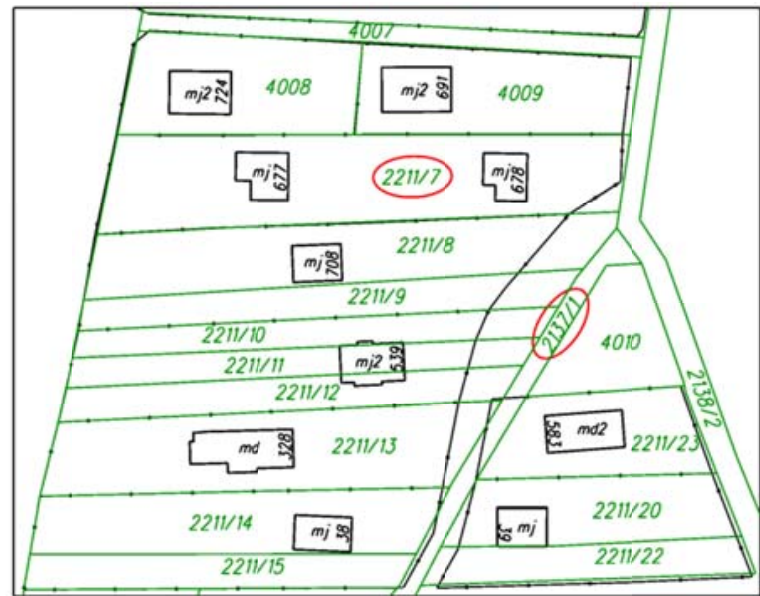

b)

Fig.1. Part of cadastral map created on the basis of the map in the scale 1:2880, a) before modernization, b) after modernization

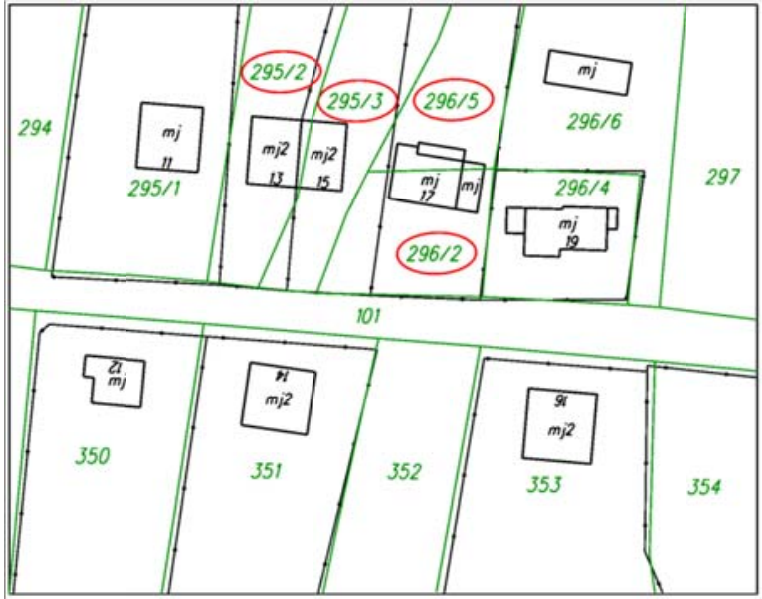

a)

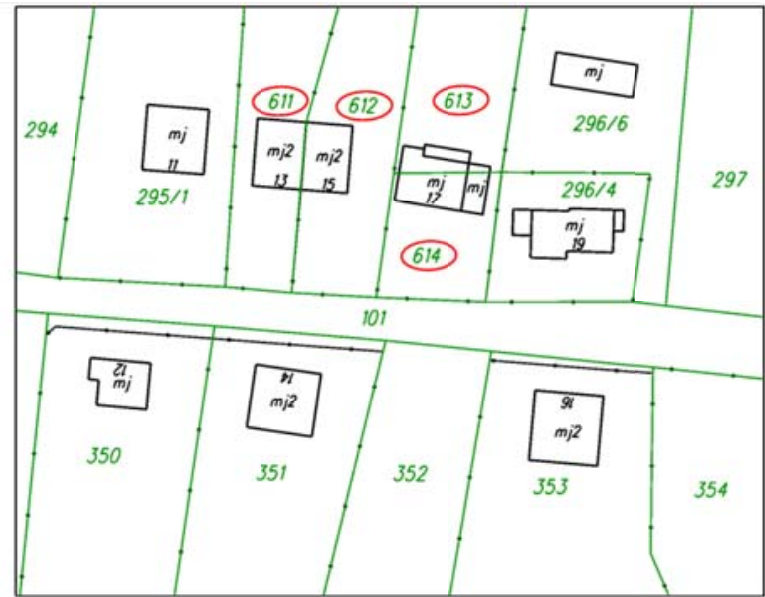

b)

Fig.2. Part of cadastral map created on the basis of the map in the scale 1:2000, a) before modernization, b) after modernization

Fig. 2 shows a methodology based on the modernization of the map in the scale 1: 2000 created on the basis of a photomap. Determination of the course of borders for parcels No. 350, 351, 352, 353, was performed according to a c:alm state of use, which does not raise methodological and formal-legal objections. But problematic seems to be the determination of the borders of the parcels No. 295/2, 295/3, 296/5 i $296 / 2$. Determination of the course of borders in this situation, according to the state 
of calm state of use resulted in a gross change in the configuration and surfaces of the parcels. The question then arises if the modernization can serve the purposes of regulation of borders of neighboring properties, legalizing informal rotation of the land (Karabin and Karabin, 2012).

Table 1 shows the results of study for the selected 20 cadastral precincts with cadastral map in the scale 1: 2000. Columns 3-12 show the number of parcels and its percentage according to established criteria of data sources (named as ZRD). Columns 13 and 14 show the number of parcels created on the basis of the data sources named as ZRD 3-5, for which difference of the surfaces in reference to the surfaces of the cadastral parcel, exceeds the established criterion of $2 \%$. The criterion determining the possibility of changing the parcel area without changing its number and configuration was not included in the currently applicable Regulation on $\mathrm{EGiB}$. Therefore, it was considered reasonable to adopt the surface criterion in accordance with the technical guidelines G-5.4 currently not in force.

Table 1. Distribution of parcels according to established criteria of data source for the area with the cadastral map in the scale 1:2000

\begin{tabular}{|c|c|c|c|c|c|c|c|c|c|c|c|c|c|}
\hline \multirow{3}{*}{ No. } & \multirow{3}{*}{$\begin{array}{l}\text { Number } \\
\text { of } \\
\text { parcels } \\
\text { within } \\
\text { the } \\
\text { precinct }\end{array}$} & \multicolumn{10}{|c|}{ Parcels which fulfill criterion data source (named as ZDR) } & \multirow{2}{*}{\multicolumn{2}{|c|}{$\begin{array}{c}\text { Number of } \\
\text { parcels at data } \\
\text { source (named } \\
\text { as ZRD3-5) with } \\
\text { difference in the } \\
\text { area in relation } \\
\text { to the cadastral } \\
\text { area }>2 \%\end{array}$}} \\
\hline & & \multicolumn{2}{|c|}{$\begin{array}{c}\text { data source } \\
\text { ZRD1 }\end{array}$} & \multicolumn{2}{|c|}{$\begin{array}{c}\text { data source } \\
\text { ZRD2 }\end{array}$} & \multicolumn{2}{|c|}{$\begin{array}{c}\text { data source } \\
\text { ZRD3 }\end{array}$} & \multicolumn{2}{|c|}{$\begin{array}{c}\text { data source } \\
\text { ZRD4 }\end{array}$} & \multicolumn{2}{|c|}{$\begin{array}{c}\text { data source } \\
\text { ZRD5 }\end{array}$} & & \\
\hline & & Number & [\%] & Number & [\%] & Number & [\%] & Number & {$[\%]$} & Number & {$[\%]$} & Number & {$[\%]$} \\
\hline 1 & 2 & 3 & 4 & 5 & 6 & 7 & 8 & 9 & 10 & 11 & 12 & 13 & 14 \\
\hline 1 & 2301 & 410 & 18 & 387 & 17 & 897 & 39 & 257 & 11 & 350 & 15 & 990 & 66 \\
\hline 2 & 296 & 30 & 10 & 69 & 23 & 130 & 44 & 36 & 12 & 31 & 10 & 160 & 81 \\
\hline 3 & 327 & 62 & 19 & 84 & 26 & 120 & 37 & 34 & 10 & 27 & 8 & 139 & 77 \\
\hline 4 & 7127 & 1412 & 20 & 1274 & 18 & 3128 & 44 & 602 & 8 & 711 & 10 & 3274 & 74 \\
\hline 5 & 950 & 157 & 17 & 124 & 13 & 480 & 51 & 87 & 9 & 102 & 11 & 588 & 88 \\
\hline 6 & 1812 & 287 & 16 & 271 & 15 & 850 & 47 & 194 & 11 & 210 & 12 & 861 & 69 \\
\hline 7 & 1995 & 326 & 16 & 329 & 16 & 915 & 46 & 127 & 6 & 298 & 15 & 967 & 72 \\
\hline 8 & 2589 & 398 & 15 & 502 & 19 & 1008 & 39 & 201 & 8 & 480 & 19 & 1203 & 71 \\
\hline 9 & 1474 & 201 & 14 & 307 & 21 & 569 & 39 & 157 & 11 & 240 & 16 & 765 & 79 \\
\hline 10 & 1648 & 157 & 10 & 206 & 13 & 820 & 50 & 154 & 9 & 311 & 19 & 1037 & 81 \\
\hline 11 & 1312 & 190 & 14 & 209 & 16 & 637 & 49 & 124 & 9 & 152 & 12 & 532 & 58 \\
\hline 12 & 1212 & 211 & 17 & 198 & 16 & 538 & 44 & 102 & 8 & 163 & 13 & 697 & 87 \\
\hline 13 & 891 & 99 & 11 & 135 & 15 & 439 & 49 & 98 & 11 & 120 & 13 & 480 & 73 \\
\hline 14 & 2568 & 457 & 18 & 501 & 20 & 993 & 39 & 187 & 7 & 430 & 17 & 1098 & 68 \\
\hline 15 & 2930 & 401 & 14 & 503 & 17 & 1397 & 48 & 308 & 11 & 321 & 11 & 1496 & 74 \\
\hline 16 & 3545 & 550 & 16 & 580 & 16 & 1460 & 41 & 257 & 7 & 698 & 20 & 1831 & 76 \\
\hline 17 & 1010 & 137 & 14 & 167 & 17 & 469 & 46 & 110 & 11 & 127 & 13 & 526 & 75 \\
\hline 18 & 1169 & 203 & 17 & 207 & 18 & 520 & 44 & 102 & 9 & 137 & 12 & 625 & 82 \\
\hline 19 & 949 & 183 & 19 & 229 & 24 & 368 & 39 & 80 & 8 & 89 & 9 & 369 & 69 \\
\hline 20 & 1404 & 250 & 18 & 293 & 21 & 611 & 44 & 138 & 10 & 112 & 8 & 620 & 72 \\
\hline & Minimum & & 10 & & 13 & & 37 & & 6 & & 8 & & 58 \\
\hline & Maximum & & 20 & & 26 & & 51 & & 12 & & 20 & & 88 \\
\hline & Average: & & 16 & & 18 & & 44 & & 9 & & 13 & & 75 \\
\hline
\end{tabular}

While for the next 20 investigated precincts the only valid map is a cadastral map of former Austrian partition in the scale 1:2880. The cadastral map after a proper calibration and transformation of coordinates of border points to the current coordinate system, in most cases meets the accuracy criteria of precision of $3 \mathrm{~m}$ (Taszakowski, 2012). Table 2 shows the results of study for the selected cadastral precincts with cadastral map in the scale 1: 2880, carried out according to the same criteria that were used for the first area of research. 
Table 2. Distribution of parcels according to established criteria of data source for the area with the cadastral map in the scale 1:2880

\begin{tabular}{|c|c|c|c|c|c|c|c|c|c|c|c|c|c|}
\hline \multirow{3}{*}{ No. } & \multirow{3}{*}{$\begin{array}{l}\text { Number } \\
\text { of } \\
\text { parcels } \\
\text { within } \\
\text { the } \\
\text { precinct }\end{array}$} & \multicolumn{10}{|c|}{ Parcels which fulfill criterion data source (ZDR) } & \multirow{2}{*}{\multicolumn{2}{|c|}{$\begin{array}{c}\text { Number of } \\
\text { parcels at data } \\
\text { sources (named } \\
\text { as ZRD3-5) with } \\
\text { difference in the } \\
\text { area in relation } \\
\text { to the cadastral } \\
\text { area }>2 \%\end{array}$}} \\
\hline & & \multicolumn{2}{|c|}{$\begin{array}{l}\text { data source } \\
\text { ZRD1 }\end{array}$} & \multicolumn{2}{|c|}{$\begin{array}{c}\text { data source } \\
\text { ZRD2 }\end{array}$} & \multicolumn{2}{|c|}{$\begin{array}{l}\text { data source } \\
\text { ZRD3 }\end{array}$} & \multicolumn{2}{|c|}{$\begin{array}{l}\text { data source } \\
\text { ZRD4 }\end{array}$} & \multicolumn{2}{|c|}{$\begin{array}{l}\text { data source } \\
\text { ZRD5 }\end{array}$} & & \\
\hline & & Number & {$[\%]$} & Number & {$[\%]$} & Number & {$[\%]$} & Number & {$[\%]$} & Number & {$[\%]$} & Number & {$[\%]$} \\
\hline 1 & 2 & 3 & 4 & 5 & 6 & 7 & 8 & 9 & 10 & 11 & 12 & 13 & 14 \\
\hline 1 & 6867 & 686 & 10 & 831 & 12 & 1785 & 26 & 610 & 9 & 2955 & 43 & 4590 & 86 \\
\hline 2 & 5638 & 620 & 11 & 507 & 9 & 1731 & 31 & 443 & 8 & 2337 & 41 & 3590 & 80 \\
\hline 3 & 12600 & 882 & 7 & 987 & 8 & 2646 & 21 & 630 & 5 & 7455 & 59 & 9268 & 86 \\
\hline 4 & 9925 & 1091 & 11 & 1098 & 11 & 2679 & 27 & 592 & 6 & 4465 & 45 & 5930 & 77 \\
\hline 5 & 7474 & 897 & 12 & 742 & 10 & 2914 & 39 & 671 & 9 & 2250 & 30 & 4963 & 85 \\
\hline 6 & 11318 & 905 & 8 & 1120 & 10 & 3169 & 28 & 453 & 4 & 5671 & 50 & 7958 & 86 \\
\hline 7 & 14429 & 1154 & 8 & 1427 & 10 & 2741 & 19 & 861 & 6 & 8246 & 57 & 9825 & 83 \\
\hline 8 & 7251 & 725 & 10 & 940 & 13 & 1885 & 26 & 502 & 7 & 3199 & 44 & 4462 & 80 \\
\hline 9 & 5500 & 605 & 11 & 771 & 14 & 1760 & 32 & 550 & 10 & 1814 & 33 & 2967 & 72 \\
\hline 10 & 3433 & 550 & 16 & 514 & 15 & 1373 & 40 & 302 & 9 & 694 & 20 & 1596 & 67 \\
\hline 11 & 5046 & 605 & 12 & 706 & 14 & 1412 & 28 & 503 & 10 & 1820 & 36 & 2957 & 79 \\
\hline 12 & 8295 & 746 & 9 & 912 & 11 & 2157 & 26 & 664 & 8 & 3816 & 46 & 5143 & 77 \\
\hline 13 & 18337 & 1283 & 7 & 1820 & 10 & 3667 & 20 & 732 & 4 & 10835 & 59 & 12707 & 83 \\
\hline 14 & 6241 & 748 & 12 & 931 & 15 & 2434 & 39 & 432 & 7 & 1696 & 27 & 3254 & 71 \\
\hline 15 & 7124 & 641 & 9 & 793 & 11 & 2707 & 38 & 560 & 8 & 2423 & 34 & 4620 & 81 \\
\hline 16 & 5483 & 767 & 14 & 957 & 17 & 1973 & 36 & 490 & 9 & 1296 & 24 & 2983 & 79 \\
\hline 17 & 6670 & 800 & 12 & 867 & 13 & 2134 & 32 & 531 & 8 & 2338 & 35 & 4295 & 86 \\
\hline 18 & 4857 & 825 & 17 & 789 & 16 & 1896 & 39 & 483 & 10 & 864 & 18 & 2552 & 79 \\
\hline 19 & 7045 & 704 & 10 & 968 & 14 & 2396 & 34 & 243 & 3 & 2734 & 39 & 4752 & 88 \\
\hline 20 & 5653 & 847 & 15 & 867 & 15 & 2148 & 38 & 338 & 6 & 1453 & 26 & 3367 & 85 \\
\hline & Minimum & & $\overline{77}$ & & $=8$ & & 19 & & $\overline{3}$ & & $\overline{c 18}$ & & $\bar{~} 67$ \\
\hline & Maximum & & 17 & & 17 & & 40 & & 10 & & 59 & & 88 \\
\hline & Average: & & 11 & & 12 & & 31 & & 7 & & 38 & & 81 \\
\hline
\end{tabular}

The results shown in Table 1 and 2 are consistent regardless of the type of the starting material. Only for $34 \%$ of the parcels in the first case and $23 \%$ in the second case the legal boundaries were established, as the most reliable source of data which are materials accepted for National Geodetic and Cartographic Resource (named as ZRD1) were used here as well as land surveying results preceded by determining the course of borders (named as ZRD2). Photogrammetric measurements preceded by determining the course of borders (named as ZRD3) were used respectively to $44 \%$ i $31 \%$ of the parcels. As can be seen for almost half of the objects the numerical description of the boundaries was determined with an error greater than the limit value, ie. 0,3m [\$61.1 Reg. EGiB]. Photogrammetric measurements not preceded by determining the course of borders (named as ZRD4) have only been used for about $10 \%$ of the parcels.

The source information in the range of data source named as ZRD5 (screen vectorization of cadastral raster map without the use of linear measurement), were used in approximately $13 \%$ of the first group of research objects and up to nearly $40 \%$ in the second group. This is due to the fact that the second object includes areas where in the vast majority of cases the cultivation was abandoned (therefore borders of use are not visible on the ground).

The use of the data source named as ZRD4-5 does not meet the accuracy established in the current regulation on EGiB in force. In the analyzed cases, these sources were used respectively in $22 \%$ and $45 \%$ to determine the course of borders. Areas of the parcels resulting from the obtaining of the borders using data source named as ZRD3-5 differ by more than $2 \%$ of the cadastral area in $80 \%$ of cases. This 
large number of parcels with modified area shows a low reliability of the methodology adopted. This figure confirms that the data source which are photogrammetric measurements preceded by determining the course of borders do not meet the required accuracy. It seems that the reason for this is the wrong way of determining the course of borders. It takes place solely on the basis of approval of the course of the border by the owner, based on the state of use shown in the image of the orthophotomap.

So raises the question, if such a manner of carrying out modernization does not undermine the credibility of the land and building cadastre as a public resource. Is it not only changing the form of the cadastral map from analog to electronic?

\section{Conclusions}

The modernization of the land and buildings cadastre is a necessary project to implement on the area of the whole country in the nearest future. This problem is particularly evident on the area of the former Austrian cadastre, where the principal base maps are old cadastral maps and new maps created on the basis of photomaps.

The study showed, that the use in the process of modernization of the land and buildings cadastre, sources of information from the land surveying, give fully satisfactory results. The use of photogrammetric measurements is a solution more economical in terms of financial and time. However, it carries with it the danger that the results do not meet the standards of accuracy for the position of border points. The results of the study showed, that on average $80 \%$ of the parcels after modernization has an area different from the cadastral area of over $2 \%$. Hence the conclusion, that the photogrammetric technology could be used as a measurement method only for the borders of parcels established in advance in the land and signaled on the ground.

The changes of law have not led to the development of clear solutions and practical applications for the all cases. The problem is mainly due to the quality of the source material existing in the area. According to the current legislation (Regulation on $\mathrm{EGiB}$ ) in rural areas there is a duty to identify borders only in relation to built-up areas. This solution, however, is not the best. In rural areas, especially in the villages located in the vicinity of large cities, rapid growth of urban areas can be observed. Therefore, it is necessary to extend the obligation to perform geodetic measurements (for the EGiB modernization) for land envisaged as future urban and investment areas. These measures seem necessary for a broadly understand process of real estate management and maintenance of spatial order.

In areas where the course of borders was not established, in the EGiB database the boundaries of parcels from analogue cadastral map should remain and the areas of the parcels should correspond to the pre-modernization state.

According to the authors modernization can not serve the purposes of adjusting the boundaries of neighboring properties, legalizing informal rotation of the land.

\section{References}

Cymerman R., Goraj S., Nowak A., Ofierska E., Przybyłowski K., Surowiec S. (1982): Ewidencja gruntów / Land cadastre. PWN, Warszawa; 
Fedorowski W. (1974): Ewidencja gruntów / Land cadastre. PPWK, Warszawa;

Hanus P., Hycner R., Kwartnik Pruc A. (2013): Analiza terminologiczna wybranych problemów katastru i zagadnień pokrewnych, cz. II / Analysis of terminology of selected problems of cadastre and related issues, part II. Magazyn Geoinformacyjny Geodeta no 11;

Hycner R. (2004): Podstawy katastru / Basics of the cadastre. Wydawnictwa AGH. Kraków;

Karabin M., Karabin M. (2012): Problematyka przyjęcia granic nieruchomości do podziału w aspekcie jednolitości wykonywania prac geodezyjnych / Problems of acceptance of the borders of the property to be divided in terms of uniformity of geodetic surveying performance. Studia i Materiały Towarzystwa Naukowego Nieruchomości, Olsztyn, Vol.20 Nr 4, 133-146;

Mika M., Siejka M. (2012): Wpływ geograficznych i historycznych uwarunkowań na identyfikację granic nieruchomości na przykładzie katastru austriackiego / The influence of geographical and historical conditions on the identification of borders of the real estate on the example of the Austrian cadastre. Acta Scientiarum Polonorum. Administratio Locorum. Olsztyn. 11(4), 65-74;

Przewięźlikowska A., Skotnicki K. (2001) Wykorzystanie pruskich i niemieckich oraz rosyjskich źródłowych materiałów katastralnych dla potrzeb współczesnych, wybranych prac geodezyjnych i zagadnień prawnych / The use of the Prussian and German and Russian source cadastral materials for the needs of modern selected geodetic works and legal issues. Geodezja vol. 7 (1), 55-67;

Taszakowski J. (2012): Sposób wykorzystania map katastralnych w skali 1:2880 dla potrzeb współczesnych prac geodezyjno-prawnych / The use of cadastral maps in the scale of 1: 2880 for the needs of modern surveying and legal work. Infrastruktura i ekologia terenów wiejskich, 3/IV. Kraków: PAN, 131-142;

Wilkowski W. (2005): Historia katastru w Polsce /The history of the cadastre in Poland. Przegląd Geodezyjny Nr 7;

Wilkowski W., Budzyński T., Sobolewska-Mikulska K., Pułecka A. (2006): Współczesne problemy katastru i gospodarki nieruchomościami / Contemporary problems of cadastre and real estate management. Oficyna Wydawnicza PW, Warszawa;

\section{The legal acts}

The Act of 17 May 1989. Geodetic and Cartographic Law (Journal of Laws of 2010 No. 193, item. 1287 with amendments);

Decree of 2 February 1955. on land and buildings cadastre, (Journal of Laws No. 6 , item. 32); 
Regulation of the Minister of Building dated December 6, 1950 on the procedures for the organization, establishing and running land and building cadastre. (Journal of Laws No. 57, item. 520);

Regulation of the Ministers of Agriculture and Municipal Economy of June 28, 1955 on the procedures for the reporting and making changes in the data included in the land and buildings cadastre (Journal of Laws No. 27, item. 159 with amendments);

Regulation of the Ministers of Land Management and Building and Agriculture and Food Economy of December 17, 1996 on the the land and building cadastre, (Journal of Laws No. 158, item. 813);

Regulation of the Minister of Regional Development and Building of March 29, 2001 on the the land and building cadastre, (Journal of Laws No. 38, item. 454);

Regulation of the Minister of Administration and Digitization of November 29, 2013 changing the regulation on the the land and building cadastre. (Journal of Laws of 2013, item. 1551);

Regulation of the Ministers of Agriculture and Municipal Economy of February 20, 1969 on the land cadastre, (M. P. Nr 11, item. 98, from 1988. Nr 7, item.62);

\section{Authors:}
Monika Siejka ${ }^{1)}$, rmwiech@cyf-kr.edu.pl
Marek Ślusarski ${ }^{1)}$, rmslusar@cyfronet.pl
Monika Mika ${ }^{1)}$, mika.monika@interia.pl
1) Department of Land Surveying
University of Agriculture in Krakow, Poland 